\title{
The Contribution of Students' Motivation and Vocabulary to Students' Translation
}

\author{
Listiyanti, Muh. Asrori, Endang Setyaningsih \\ English Education Department \\ Sebelas Maret University
}

\author{
Email : listiyantt@gmail.com
}

\begin{abstract}
This research is aimed to find out the contribution of: (1) students' motivation to students' translation; (2) students' vocabulary to students' translation ability; and (3) students' motivation and students' vocabulary, to students' translation. This correlational study involved 35 students of the sixth semester students of English Education Department of Teacher Training and Education Faculty of a University in Surakarta. The technique of choosing the sample was cluster random sampling. Data were collected through questionnaire and test. Single Correlation and Multiple Linear Regressions were used to analyze the data. The research findings show that: (1) motivation brings $10.30 \%$ contribution to translation; (2) vocabulary brings $29.58 \%$ contribution to translation; and (3) motivation and vocabulary simultaneously bring $39.88 \%$ contribution to translation. Based on the study, it can be implied that motivation and vocabulary are important factors that give contribution to translation.
\end{abstract}

Keywords: contribution, motivation, vocabulary, translation

Abstrak

Penelitian ini bertujuan untuk menemukan kontribusi: (1) motivasi siswa terhadap ketrampilan menerjemahkan, (2) kosa kata siswa terhadap ketrampilan menerjemahkan, (3) motivasi siswa dan kosa kata siswa, terhadap ketrampilan menerjemahkan. Penelitian korelasional ini melibatkan 35 semester enam di Pendidikan Bahasa Inggris di Universitas di Surakarta. Teknik yang digunakan untuk pemilihan sample adalah sample kelompok acak. Data dikumpulkan dengan menggunakan angket dan tes. Korelasi tunggal dan korelasi ganda digunakan untuk menganalisis data. Hasil penelitian menunjukan bahwa: (1) motivasi $10.30 \%$ berpengaruh terhadap ketrampilan menerjemahkan, (2) kosa kata $29.58 \%$ berpengaruh terhadap ketrampilan menerjemahkan, dan (3) motivasi dan kosa kata 39.88\% berpengaruh terhadap ketrampilan menerjemahkan. Berdasarkan penelitian ini, dapat disimpulkan bahwa motivasi dan kosa kata adalah factor penting yang memberikan kontribusi terhadap ketrampilan menerjemahkan.

Keywords: pengaruh, motivasi, kosa kata, ketrampilan menerjemahkan 
Translation is one skill that is very necessary for students in learning foreign language. In translating, students have to be able to appropriately transfer the meaning or message from foreign language (English) into their first language. There are several factors influencing translation ability such as motivation and vocabulary. Motivation has basic role for students in acquiring a language. Students will easily learn something when they have high motivation. Vocabulary helps students in finding equivalent meaning to convert a text. Thus, motivation and vocabulary can give benefit to translation.

Nowadays, many instructions of technology and information are written in English. Besides, for students, their textbooks and reference books are also in written form. Translation can help people to convert ideas and equipment that cannot be provided with in our daily life (Abdul-Hassan in his "Translation, Grammatically Viewed"). In line with Abdul-Hassan, Grosjean in Marguerite M. and Kenji Hakuta (1991) states "Translation is an everyday activity, a part of their lives as bilinguals" (p.142). Besides, according to Lambert in Marguerite M. and Kenji Hakuta (1991)

"Studies of balanced bilinguals (bilinguals who have roughly equivalent abilities in the two languages) have suggested that bilingualism has a positive effect on cognitive development, especially under certain condition of additive bilingualism where both languages are supported academically and emotionally by both community and the society at large" (p.141).

Moreover, translation is one of basic skills in learning language that students must master. Hatim \& Munday (2004), state that process of translation 
deals with finding the equivalent meaning and choice of individual words and phrases from source language into target language. In addition, translation is not just transferring words from source language into target language, but also finding the equivalent meaning or message in the source language into target language. Besides, students must not plod on, word by word or sentence by sentence, but they must block out and consider the whole text or sentence and find the closest meaning before they have to convey the whole sense in the text (Belloc in Basnet, 2002).

Students must have a wide knowledge about foreign language and its culture including an extensive vocabulary (Newmark, 1991). Vocabulary helps students in finding equivalent meaning to convert a text. Therefore, to find the equivalent meaning, students must know the vocabulary and the meaning of source language and what is more, students have to know the culture or history from target language.

Vocabulary is very important element of a language as the majority of meaning is carried lexically (Campillo in her article "Teaching and Learning Vocabulary: an Introduction for English Students"). Vocabulary is a necessary material for all communication. Lack of vocabulary makes misunderstanding or failure in communication. Catford in Marguerite M. and Kenji Hakuta (1991) states "meaning in a text can be analyzed at many different levels or units. There are the meanings of the individual words, of the phrases, and clause that constitute the sentence; there are the meanings of the individual sentences that constitute a text, and there is a meaning of the text as a whole" (p. 145). 
In order to have good translation ability, a language learner must learn a lot, practice a lot, know sentence structure well, and have a wide range of vocabulary. No matter how successfully the students learn grammar, no matter how well the sounds of L2 are mastered, but without words to express a wide range of meaning, a communication in an L2 cannot happen in a meaningful way (McCarthy in Rosa M. L. Campillo in her article "Teaching and Learning Vocabulary: An Introduction for English Students"). Mastering vocabulary will support students in increasing their translation ability. Sometimes, learners find some words which are not understandable when they translate a text. Since full understanding of a word often requires knowing how native speakers feel about what the word represents, some meanings cannot be found in a dictionary (Virginia, 1983). Hence, learners need larger knowledge of word to overcome that problem. That is why students should have wide vocabulary.

Socio-psychological aspects, such as identity, attitude, and motivation are several factors that can influence the students' success in leaning target language (Butler in Sultan, 2012). Santrock (2011) states "motivation is a crucial aspect in learning” (p.437). It is because students' motivation is a key factor that influences the rate and success of second or foreign language learning (McDonough; Ellis, in Al-Tamimi \& Munir Shuib, 2009). Therefore, motivation has basic role for students in acquiring a language. Students will easily learn something when they have high motivation.

Dweck \& Elliot in Elliot, Kratochwill, et al (2000) state that motivation can affects the learning strategies and cognitive processes of an individual's task. 
Students who have high motivation will try to get new knowledge and skill. According to Shawn, Lori \& Ashely (2005):

"Learning and motivation are equally essential for performance: learning enables us to acquire new knowledge and skills, and motivation provides the impetus for showing what we have learned. So, it can be seen that more-motivated people achieve at higher level" (p. 150).

In addition, motivation also plays an important role in process of translating. Motivation helps students to build their confidence. Students with high motivation feel confidence with their own ability to perform well in translation. In addition, they will increase their competence in translation. "The motivated learners are more receptive than those who are not motivated" (Bailey in Alazoumi, 2014, p.124). Students may face many problems when translating. Hence, learners must have good self-confidence and motivation, particularly when facing a problem. They need a high motivation in order to keep trying to solve the problem, especially in this case is translation. Elliot, Kratochwill, et al (2000) state "motivation is an internal state that makes us to do something, pushes us in particular direction, and keeps us involved in particular activities" (p.332). Motivation can increase an individual's energy and activity level (Pintrich, Marx, \& Boyle in Elliot, Kratochwill, et al, 2000, p. 332).

Although there are many factors that contribute to translation, the researcher highlights the link of motivation, vocabulary and translation in this research. Therefore, the following hypotheses in this research were outlined and examined: (1) There is a positive correlation between students' motivation and students' translation of the sixth semester students of English Education 
Department of University in Surakarta, (2) there is a positive correlation between vocabulary and translation of the sixth semester students of English Education Department of University in Surakarta, (3) there is a positive correlation between students' motivation and vocabulary and translation of the sixth semester students of English Education Department of University in Surakarta.

Based on the hypotheses above, the purpose of this research is to investigate the contribution of: (1) motivation to translation; (2) vocabulary to translation; and (3) motivation and vocabulary simultaneously to translation.

\section{Research Method}

This research uses correlational method. This research is one of quantitative researches that measure on two variables. According to Wiersma (2000), correlational research concerns in two or more variables. Moreover, the writer chooses all of the sixth semester students of English Education Department of Teacher Training and Education Faculty of of a University in Surakarta as population. There are three classes: A, B, and SBI. Class A consists of 35 students; class B consists of 35 students; and class SBI consists of 19 students.

The sample of this research consists of 35 students. The students come from class B. The writer uses cluster random sampling to choose the sample. In cluster random sampling, the writer subdivides the population into subgroups called cluster. The writer then randomly selects a sample of cluster and then randomly selects members of the cluster sample to serve as the population sample (Goddard and Melville, 2001). The tests were administered at English Education Department of University in Surakarta in two days to minimize fatigue. The 
researcher used a test to measure students' vocabulary and translation. The tests were objective test in the form of multiple choices test.

After collecting the data, the next step is testing the hypotheses. Below are the statistical hypotheses of the correlation between student's motivation $\left(\mathrm{X}_{1}\right)$ and student's translation $(\mathrm{Y})$; student's vocabulary mastery $\left(\mathrm{X}_{2}\right)$ and student's translation $(\mathrm{Y})$; and between student's motivation $\left(\mathrm{X}_{1}\right)$, student's vocabulary mastery $\left(\mathrm{X}_{2}\right)$ and student's translation $(\mathrm{Y})$.

\section{First Hypothesis}

$$
\begin{aligned}
& H_{0}=r_{x 1 y} \leq 0 \\
& H_{a}=r_{x 1 y}>0
\end{aligned}
$$

2. Second Hypothesis

$$
\begin{aligned}
& H_{o}=r_{x 2 y} \leq 0 \\
& H_{a}=r_{x 2 y}>0
\end{aligned}
$$

3. Third Hypothesis

$$
\begin{aligned}
& \mathrm{H}_{\mathrm{o}}=\mathrm{R}_{\mathrm{o}} \leq 0 \\
& \mathrm{H}_{\mathrm{a}}=\mathrm{R}_{\mathrm{o}}>0
\end{aligned}
$$

Where:

$\mathrm{H}_{\mathrm{o}}=$ Null hypothesis

$\mathrm{H}_{\mathrm{a}}=$ Alternative hypothesis 
$r_{x y}=$ the value of $r$ test

$\mathrm{R}_{\mathrm{o}}=$ the value of $\mathrm{R}$ test

The analogy of the hypothesis formula above is that when the value of $r_{x y}$ is 0 , it means that there is no correlation. When the value of $r_{x y}$ is lower than 0 , it means that there is negative correlation. On the contrary, when the value of $r_{x y}$ is higher than 0 , it means that there is positive correlation or it has correlation. The null hypothesis will be rejected and the alternative hypothesis will be accepted if the value of $r_{x y}$ or $R_{o}$ is higher than $r_{t}$. Meanwhile, the alternative hypothesis will be rejected and the null hypothesis will be accepted if the value of $r_{x y}$ or $R_{o}$ is lower or the same as rt.

The three of data of students' motivation, the data of students' vocabulary and the data of students' translation are analyzed by using Product Moment Formula and Multiple Linear Regressions. Product Moment Formula is used to test the first and second hypothesis, whether there is positive correlation between students' motivation and student's translation; student's vocabulary and student's translation. Besides, Multiple Linear Regressions is used to test the third hypothesis which says that there is a positive correlation between student's motivation and student's vocabulary and student's translation.

\section{Research Findings and Discussion}

In this part of the research, the correlation between students' motivation and translation, the correlation between students' vocabulary and translation and 
the correlation between students' motivation and vocabulary simultaneously, and translation were presented. Before analysing the data using Product Moment Formula and Multiple Linear Regressions, the researcher tests the normality of the data. The results showed that the data of participants' motivation, vocabulary, and translation are normally distributed. So, the next statiscal tests in this research could be applied. The result shows that the regression is linear and significant. Therefore, the rise and the fall of students' motivation and vocabulary are followed linearly by the rise and the fall of student's translation.

When examining the simple correlations associated with the regressions, the researcher noted that performance of students' motivation was significantly related with performance of translation $(\mathrm{r}=0.4012, p=0.05)$. It means that there is a moderate positive correlation between the two variables. In order to investigate the correlation between vocabulary and translation Pearson Product-moment correlation was also computed. The result showed that the coefficient correlation $(\mathrm{r}=0.5815, p=0.05)$ is statistically significant. This means that there is significant correlation between vocabulary and translation.

The multiple regression was run to assess the correlation between motivation and vocabulary simultaneously for students' translation. It was found out that there is significant correlation $(\mathrm{r}=0.6315, \mathrm{p}=0.05)$ between motivation and vocabulary simultaneously and translation. This means that students' motivation and vocabulary simultaneously were significant predictors of students' translation and approximately $39.88 \%$ of the total variance for students' translation was explained by their motivation and vocabulary simultaneously. 
From the testing of the first hypothesis, it is known that the first hypothesis, saying that there is a positive correlation between students' motivation and students' translation is accepted. The result of the computation shows that the coefficient correlation $\left(\mathrm{r}_{\mathrm{x} 1 \mathrm{y}}\right)$ between students' motivation $\left(\mathrm{X}_{1}\right)$ and students' translation $(\mathrm{Y})$ is 0.4012 and after being consulted to the $r$-table, $r_{o}(0.4012)>r_{t}$ (0.334). It means that there is a significant, positive correlation between students' motivation and students' translation of the sixth semester students of English Education Department of a University in Surakarta. It is also found that the value of $\mathrm{r}^{2}$ (coefficient determination) is 0.1610 . It means that $16.10 \%$ variance of $\mathrm{Y}$ is determined by $\mathrm{X}_{1}$ and $83.90 \%$ variance of $\mathrm{Y}$ is determined by other factors. Based on Alazoumi (2014), the reason for students in learning English becomes a part of motivation. Motivation becomes a factor that creates a desire for students to learn. If students choose to learn translation deeply, then the students love to explore more. Then, it means that the increase of students' motivation will be followed by the increase of students' translation ability. Alazoumi (2014) also states, "the importance of motivation in EFL learning process has always been recognized due to the fact that it is one of the most important factors which decide the success or failure of the process" (p.124). Hence, students' motivation can be a factor that decides the success or failure of the translation process. In addition, the relative contribution of students' motivation toward students' translation is $25.84 \%$ while the effective contribution is $10.30 \%$. Therefore, it can be concluded that $10.30 \%$ of students' translation is determined by students' motivation. 
From the testing of the second hypothesis, it is known that the second hypothesis, saying that there is a positive correlation between students' vocabulary and students' translation is accepted. The result of the computation shows that the correlation coefficient $\left(\mathrm{r}_{\mathrm{x} 2 \mathrm{y}}\right)$ between students' vocabulary $\left(\mathrm{X}_{2}\right)$ and students' translation $(\mathrm{Y})$ is 0.5711 and after being consulted to the r-table, $r_{\mathrm{o}}$ $(0.5711)>r_{t}(0.334)$. It means that there is a significant, positive correlation between students' vocabulary and students' translation of the sixth semester students of English Education Department of a University in Surakarta. It also found that the value of $r^{2}$ (coefficient determination) is 0.3382 . It means that $33.82 \%$ variance of $\mathrm{Y}$ is determined by $\mathrm{X}_{2}$ and $66.18 \%$ variance of $\mathrm{Y}$ is determined by other factors. Then, it means that the increase of students' vocabulary will be followed by the increase of students' translation ability. The relative contribution of students' vocabulary toward students' translation is $74.16 \%$ while the effective contribution is $29.58 \%$. Therefore, it can be concluded that $29.58 \%$ of students' translation is determined by students' vocabulary.

From the testing of the third hypothesis, it is known that the third hypothesis, saying that there is a positive correlation between students' motivation and students' vocabulary simultaneously and students' translation is accepted. The result of the computation shows that the correlation coefficient $\left(\mathrm{R}_{\mathrm{o}}\right)$ between students' motivation $\left(\mathrm{X}_{1}\right)$ and students' vocabulary $\left(\mathrm{X}_{2}\right)$ simultaneously and students' translation (Y) is 0.63 and after being consulted to the F-value, $F_{o}$ $(10.615)>F_{t}$ (3.35). It means that there is a significant, positive correlation between students' motivation and students' vocabulary simultaneously and 
students' translation of the sixth semester students of English Education Department of a University in Surakarta. Then, it means that the increase of students' motivation and students' vocabulary will be followed by the increase of students' translation ability. The total effective contribution of the two independent variables to the dependent variable is $39.88 \%$.

\section{Conclusion and Suggestion}

The empirical analysis shows that there is a positive correlation between students' motivation and students' translation, there is a positive correlation between students' vocabulary and students' translation, and there is a positive correlation between students' motivation, students' vocabulary simultaneously and students' translation of the sixth semester students of English Education Department of a University in Surakarta. Judging by quantity, the vocabulary brings more contribution $(29.58 \%)$ to translation than motivation to translation $(10.30 \%)$. With regard to the result, the motivation and vocabulary simultaneously brings the contribution to translation $(39.88 \%)$.

The first suggestion would be directed to teachers or lecturers. Lecturers should be creative to make learning activity become interesting such as giving a reward or telling motivating story so the students' motivation will increase in learning English. Moreover, lecturers should help the students to enrich their vocabulary in order to help students to achieve good translation. Besides, lecturer should give more practice in translating texts to improve students' translation 
ability by translating magazine, newspaper, or letter from Source Language to Target Language.

For students, they should motivate to get success in translation by making a plan and self-monitoring. Students should improve their vocabulary through reading a lot and variety of strategies to acquire new knowledge of vocabulary. They should do many exercises in translating text to increase their translation ability. The last suggestion would be directed to other researchers. The findings of the research can be used as reference to conduct the better research which is related to students' translation.

\section{Bibliography}

Alazoumi, Fatima. (2014). Promoting Student Motivation in EFL Classroom: A Perspective on the Role of Teacher. International Journal of English Language \& Translation Studies. 2(2), 120-131 Retrieved from http://www.eltsjournal.org

Allen, Virginia French. (1983). Techniques in Teaching Vocabulary: Teaching Techniques in English as a second or Foreign Language. New York: Oxford University Press

Al-Tamimi, A., and Shuib, Munir. (2009). Motivation And Attitudes Towards Learning English: A Study Of Petroleum Engineering Undergraduates At Hadhramout University Of Sciences And Technology. GEMA Online Journal of Language Studies, Vol. 9(2) 2009. 
Basnett, Susan and Mc Guire. (2002). Translation Studies. London: Longman

Campillo, Rosa, M. L. Teaching and Learning Vocabulary: An Introduction for English Students. Articles.

Elliot, kratochwill, et al. 2000. Educational Psychology: Effective Teaching, Effective Learning third edition. USA: The McGraw-Hill Companies

Hatim, Basil, and Munday, Jeremy. (2004). Translation: An Advance Resource Book. New York: Routledge

Malakoff, Marguirete, and Hakurata, Kenji. (1991). Language Processing in Billingual Children.

Newmark, Peter. (1991). About Translation: Multilingual Matters. UK: British Library Cataloguing in Publication Data

Qasim, Abdul, H., Sh. Translation, Grammatically Viewed. University of Baghdad

Santrock, John W. (2006). Educational Psychology. Third Edition. NY: Mc.Graw

Shawn M. Glynn, et al. (2005). Motivation to Learn in General Education Programs. The Journal of General Education, Vol. 54, No. 2 (2005), pp. 150-170. Penn State University Press

Sultan, Sultan. (2014). English Medium of Instruction (EMI) in Indonesian Public Junior Secondary School: Student's Language Use, Attitudes/motivation and Foreign Language Outcomes. ACTA International TESOL Conference, Cairns Australia 4 July (2012). 